\title{
Spatio-temporal variations in urban vehicular emission in Port Harcourt city, Nigeria
}

\author{
*Utang, P. B. and Peterside, K. S.
}

http://dx.doi.org/10.4314/ejesm.v4i2.5

\begin{abstract}
The increasing high volume of road traffic and congestion is a fundamental issue in Port Harcourt metropolis. The degradation of air quality arising from these is another serious dimension of the problem. This study estimated the emissions of pollutants from vehicles during traffic peak periods within parts of the city of Port Harcourt in Nigeria. It estimated air pollutants, Carbon Monoxide, Nitrogen Oxides, Sulphur Oxides and Hydrocarbons in four sampling points. The level of variation in concentration of emissions between peak and off peak periods of traffic, and between locations was determined. Only traces of SOx were detected at all times and locations, while the concentration of $\mathrm{CO}$ detected was higher than the Federal Environmental Protection Agency limits and the recommended municipal (local) standard. This was predominantly in location A. Levels of Hydrocarbon (CxHy) detected varied in space and time, while. NOx was generally above the local and international standards in all the locations during peak traffic period. Though this study did not cover the whole city of Port Harcourt, findings from the four sampling points suggest that the city is under the threat of traffic related pollution and is possibly more susceptible given increasing population influx and vehicular traffic. Improved road network and construction of modern roundabouts could help reduce peak period traffic in the nearest future.
\end{abstract}

Key Words: Air pollution, Road intersection, Peak and off peak, traffic congestion, Vehicular emission

\section{Introduction}

The urban milieu is an obvious setting where the functionality of the system depends largely on automobile transportation. Automobile transport emissions have been identified as key factors in the deterioration of the urban air environment, constituting up to $90 \%$ of urban air pollution (USEPA, 1994). Pollution due to traffic constitute up to $90-95 \%$ of the ambient CO levels, $80-90 \%$ of NOx, and high levels of hydrocarbon and particulate matter in the world, posing a serious threat to human health (Savile, 1993).

Transportation sources account for $77 \%$ of $\mathrm{CO}$ levels, $80-90 \%$ of $\mathrm{NOx}, 36 \%$ of volatile organic compounds and $22 \%$ of particulate matter and the average concentration of $\mathrm{NO}_{2}$ found to increase by $35 \%$ due to increase in vehicular emission (USEP, 1993;
CEC, 1992). At local scales, such as city centre and congested streets, traffic can be responsible for 80-90\% of pollution and this situation is particularly severe in cities in developing countries (Odhiambo, et al, 2010). Cities have higher values of $\mathrm{CO}_{2}$ concentration in heavily congested traffic areas (Akpan and Ndoke, 1999).

Although studies such as that of Akpan and Ndoke, (1999) have been conducted for traffic congestion points within an urban milieu, peak and off peak periods have not been taken into account. Generally, exhaust gas emission concentrations vary, depending on the engine operating mode (idling, accelerating, cruising and decelerating) (Colls, 2002). Deceleration and idle are characteristics of peak traffic at road intersections, 
while high acceleration and cruise are common at off peaks. Thus a spatio-temporal variation in rate and type of air pollutant exists between and within peak and off peak periods of urban traffic.

With the emission concentration in traffic being some $10^{4}-10^{5}$ times typical ambient background and, released only a few tens of centimeters above ground level, excellent dispersion is essential (Colls, 2002; Abhishek and colls, 2010). Thus the meteorological conditions, in addition to concentration of activities, which generates emission, account for the spatial and temporal variations.

The emission of vehicle pollutants into the atmosphere is an increasingly important health issue that affects nearly everyone (Rouphail, et al, 2001). The health challenges faced by road users, passers-by, residents and business operators in traffic flash points, having high concentration of vehicular traffic during some periods of the day are worrisome issues. A comparison of the monitored and inventory emissions with acceptable standards (threshold) is useful in determining the extent of safety of road side business operators and hawkers in traffic intersection congested traffic points.

This study estimates emission levels at road intersections experiencing recurrent traffic congestion at certain periods, identified as peaks, and comparing the values with less congested periods known as off peak periods. In addition, a comparison of the different points is made in relation to the atmospheric (surface layer meteorological) conditions. This study is based on the hypotheses that: vehicular emissions during peak and off peak periods are the different; while the concentration of each pollutant is influenced by weather conditions; and that these conditions are different in space and time.

\section{Materials and Methods}

The study was conducted in Port Harcourt metropolis located in Rivers state, Nigeria. It was conducted over a period of 15 days between the $1^{\text {st }}$ and $19^{\text {th }}$ of November, 2010.
The sample frame consisted of the 10 highly notorious high traffic density junctions in Port Harcourt Metropolis. Four nodes were selected by simple random sampling. The sampled nodes include:

Nwaja Bridge Junction along Trans-Amadi Industrial Layout, (location A), Artillery Junction along Aba Road Express Way (location B), Rumuokoro Round About, (Location C) and Railway junction Woji road in Woji town (Location D) (See Fig 1).

Collection of data from the selected sites was carried out in three (3) time periods for duration of four working days of the week. These times are as follows:

$$
\begin{array}{lll}
\text { - } & 7.30 \mathrm{am}-9.00 \mathrm{am} & \text { Morning peak hours } \\
\text { - } & 1.00 \mathrm{pm}-3.00 \mathrm{pm} & \text { Off peak period } \\
\text { - } & 5.00 \mathrm{pm}-8.00 \mathrm{pm} & \text { Evening peak hours }
\end{array}
$$

This research involved the collection of data on the following air quality parameters: Carbon Monoxide (CO), Nitrogen Oxides $\left(\mathrm{NO}_{\mathrm{X}}\right)$, Sulphur Oxides $\left(\mathrm{SO}_{\mathrm{X}}\right)$, and Hydrocarbons (CxHy). The climatic elements sampled were the ambient temperature $\left({ }^{\circ} \mathrm{C}\right)$, relative humidity $(\%)$, and wind velocity $\left(\mathrm{ms}^{-1}\right)$. Air quality parameters were measured using the Testo 350XL Emission Analyzer, which is an automatic instrument that measures $\mathrm{O}_{3}, \mathrm{CO}$, $\mathrm{NO}$ (option) $\mathrm{NO}_{2}, \mathrm{SO}_{2}, \mathrm{CxHy}$ and $\mathrm{H}_{2} \mathrm{~S}$ (options), temperature and differential pressure as well as the wind velocity and direction. The relative humidity value was obtained using the Kestrel 4000 weather tracker.

Data were presented graphically and in tables, while further analysis was based on descriptive and explanatory (inferential) statistics. The descriptive statistics included measures of central tendency and variation (dispersion). The inferential statistical tool used to test the hypotheses was the Analysis of Variance (ANOVA). 


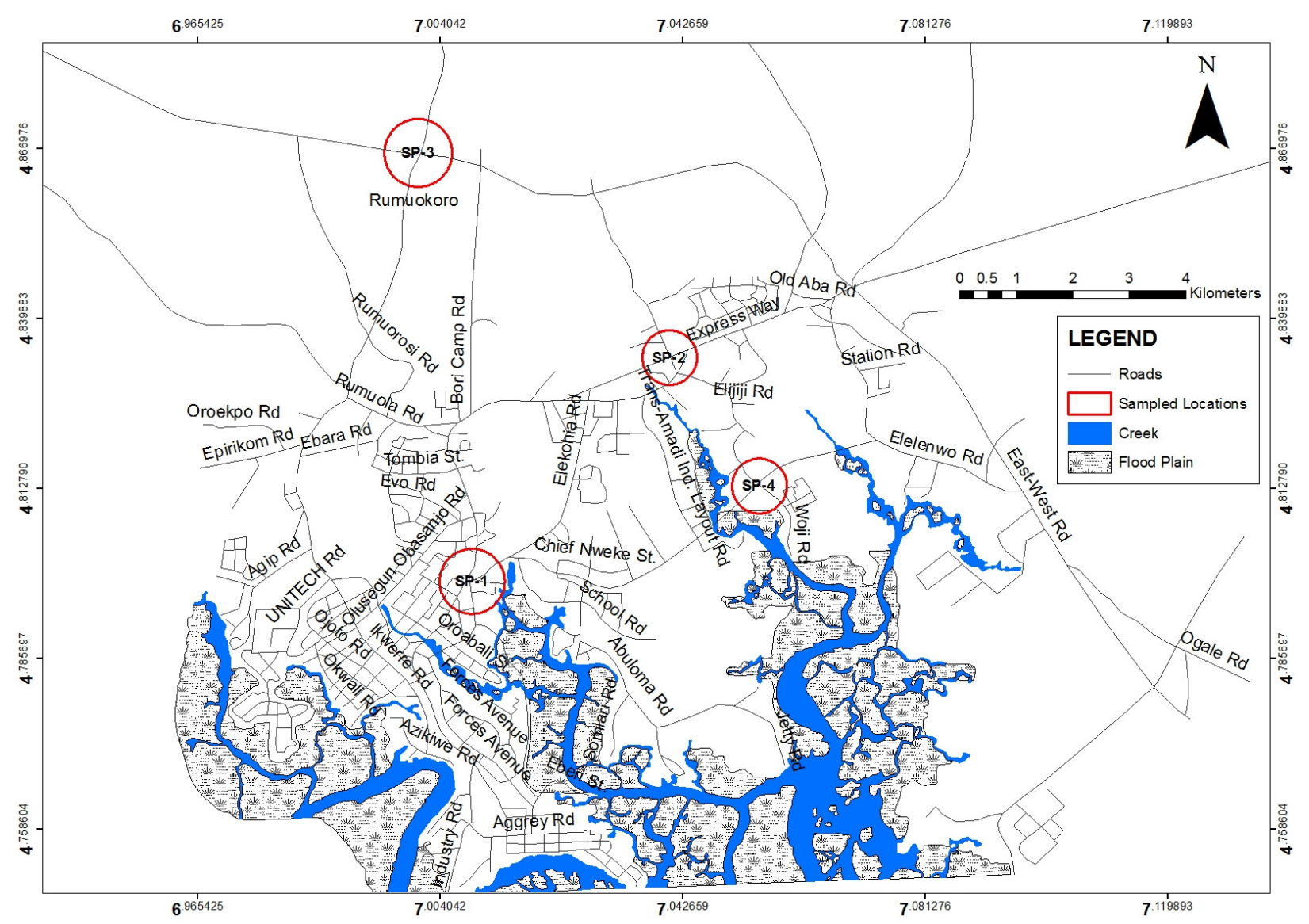

FIG 1

Map of Port Harcourt Metropolis Showing the Sampled Areas

\section{Results and Discussion}

Mean daily air quality levels during peak and off peak periods of traffic in four days at the four locations

The results as presented in table 1 show that SOx was not generally detected, whereas low concentration of NOx was detected. $\mathrm{CO}$ and $\mathrm{CxHy}$ were detected, with $\mathrm{CO}$ mostly during the evening peaks and $\mathrm{CxHy}$ during morning peak period. Off peak concentration of $\mathrm{CO}$ was experienced higher than morning peak in sample area A (Nwaja junction), while off peak CxHy concentration was higher than evening peak at location B (Artillery junction).
Generally, variation existed in air quality between the locations and period of data collection. Highest variation between locations was in the evening peaks, for $\mathrm{CO}$ and $\mathrm{CxHy}$. Both of these accounted for the highest variation during all periods.

Sulphur oxides were generally not detected in the area, so consideration was not of this air quality parameter. $\mathrm{CO}$ and $\mathrm{CxHy}$ were detected highly during the evening peak period while NOx was highest during the morning peak period and lowest or not detected during the off peak period. 
The level of each pollutant in each of the four sampling points during the morning, evening and off peak periods of traffic is represented graphically in figs 1-4.

The Figs confirm that $\mathrm{CO}$ on the average was concentrated more during evening peak during the four day of investigation, while NOx was concentrated more during morning peaks. CxHy was more concentrated in location $\mathrm{B}$ and during evening peak.

Table 1: Average emission estimates at peak and off peaks at four locations

\begin{tabular}{|c|c|c|c|c|c|c|c|}
\hline \multirow[t]{3}{*}{ LOCATION } & \multicolumn{4}{|c|}{ AIR QUALITY PARAMETERS } & \multicolumn{3}{|c|}{ METEOROLOGY } \\
\hline & \multicolumn{4}{|c|}{ Morning Peak } & \multirow[b]{2}{*}{$\begin{array}{l}\text { Wind } \\
\text { speed }(\mathrm{m} / \mathrm{s})\end{array}$} & \multirow[b]{2}{*}{$\begin{array}{ll}\text { Air } & \text { temp } \\
\left({ }^{\circ} \mathrm{C}\right) & \end{array}$} & \multirow[b]{2}{*}{$\mathbf{R} / \mathbf{H}(\%)$} \\
\hline & Sox (ppm) & CO (ppm) & NOx (ppm) & CxHy (5) & & & \\
\hline $\mathbf{A}$ & .0003 & 6.8 & $\mathbf{0 . 3 3}$ & 264.7 & 1.08 & 32.3 & 52 \\
\hline B & .0003 & 7.3 & 0.5 & 3.7 & 1.14 & 31.6 & 45 \\
\hline $\mathbf{C}$ & .0004 & 1.0 & 0.6 & 3.4 & 1.65 & 31.5 & 44 \\
\hline D & .0005 & 7.0 & 0.3 & 50.3 & 1.12 & 32.1 & 50 \\
\hline Mean & .0004 & 5.5 & 0.43 & 80.53 & 1.24 & 31.9 & 47.8 \\
\hline Std dev & & 3.02 & 0.14 & 124.75 & $0-269$ & 0.386 & 3.862 \\
\hline \multicolumn{8}{|c|}{ Evening Peak } \\
\hline $\mathbf{A}$ & 0.0005 & 24.8 & 0.6 & 10.8 & 1.17 & 35.2 & 48 \\
\hline $\mathbf{B}$ & 0.0003 & 14.7 & 1.2 & 731 & 1.13 & 35.1 & 43 \\
\hline $\mathbf{C}$ & 0.0005 & 16.2 & 1.1 & 0.5 & 1.44 & 30.3 & 28.7 \\
\hline D & 0.0008 & 8.6 & 0.9 & 70.7 & 1.25 & 33.7 & 31 \\
\hline Mean & & 16.07 & 0.95 & 203.25 & 1.25 & 33.58 & 37.67 \\
\hline Std Dev & & 6.81 & 0.26 & 353.19 & 0.138 & 2.29 & 9.31 \\
\hline \multicolumn{8}{|c|}{ Off Peak } \\
\hline$\overline{\mathbf{A}}$ & 0.00008 & 9.7 & 0.08 & 40.3 & 1.1 & 35.6 & 72 \\
\hline B & $\mathbf{0}$ & 2.5 & $\mathbf{0}$ & 0.2 & 1.2 & 36.6 & 68 \\
\hline $\mathbf{C}$ & 0.00003 & 2.8 & 0.1 & $\mathbf{0}$ & 1.14 & 34.8 & 61 \\
\hline D & 0.0002 & 3.9 & 0.0003 & 3.7 & 1.12 & 35.8 & 64 \\
\hline Mean & & 4.73 & & 11.05 & 1.14 & 35.45 & 66.25 \\
\hline Std Dev & & 3.37 & & 19.57 & 0.043 & 0.443 & 4.787 \\
\hline Grand Mean & & 8.78 & 0.48 & 98.28 & 1.21 & 36.64 & 50.7 \\
\hline Std Dev & & 6.85 & 0.42 & 212.74 & 0.230 & 1.04 & 5.99 \\
\hline
\end{tabular}

Source; Authors' Fieldwork, 2010 


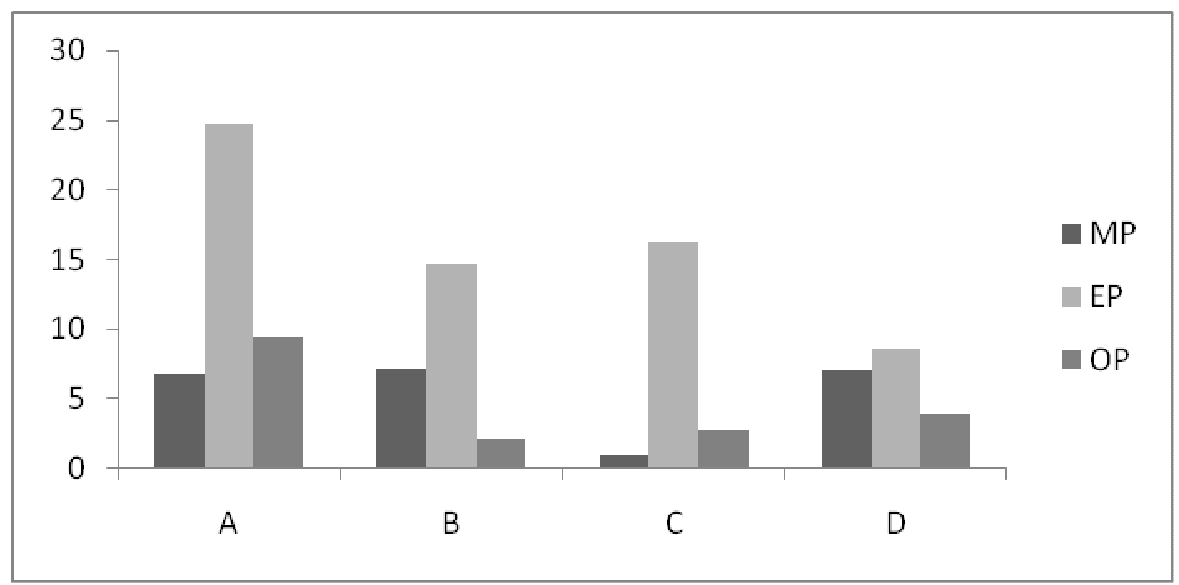

Fig 2: Average CO concentration at different locations and periods

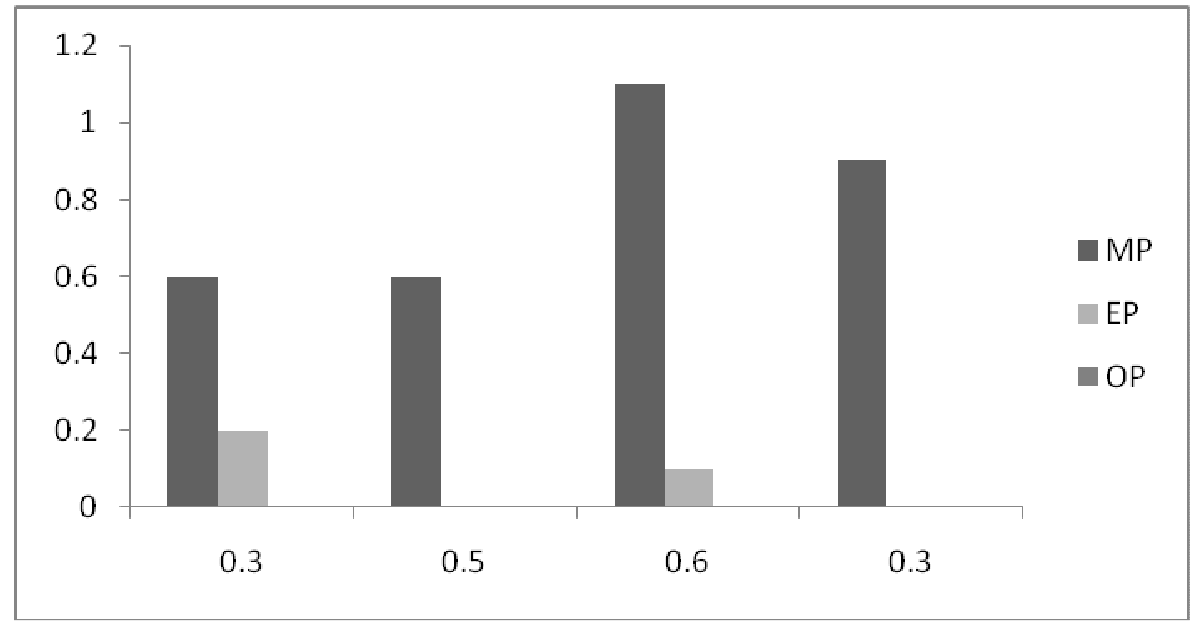

Fig 3: Estimated average NOx concentration at different locations and periods

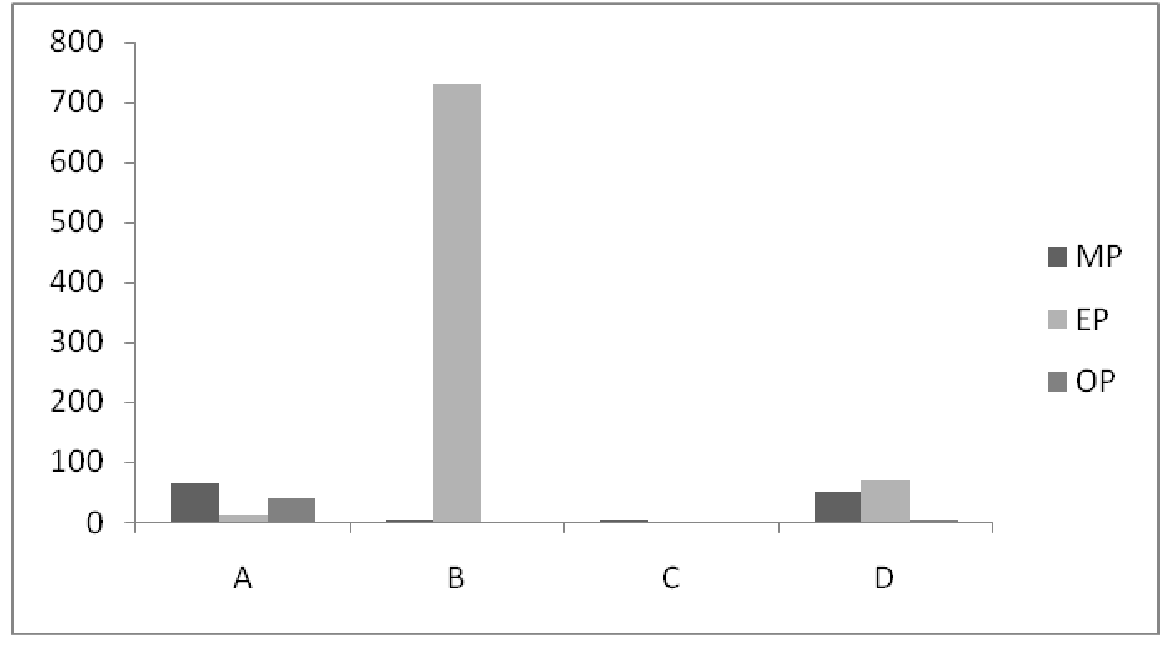

Fig 4: Estimated average $\mathrm{CxHy}$ concentration at different locations and periods 
Several mutually inclusive factors could account for the variation. Among these are variations in prevailing meteorological conditions and traffic flow (mode of operation), quality of vehicles, including age, maintenance and fuel type vehicle (i.e. diesel or petrol) (Faiz et al., 1996; Sharma and Roychowdhury (1996 in Rouphail, et al, 2001).

Because areas of concern are associated with intersections, traffic lights, queues and cars parking due to engine being temporarily switched off, driving involves repeated acceleration, idling and decelerating cycles. The low concentration on $\mathrm{CO}$ and $\mathrm{CxHy}$ during off peak could be attributed to the rate of acceleration. During this period, the combustion is efficient and there is excess air. However because combustion chambers are high during this period, NOx could be high, as indicated from the result. At peak period, characterized by deceleration, there is excess fuel, so $\mathrm{CxHy}$ are increased (Colls, 2002; Abhisheek and Colls, 2010).

Hydrocarbon (HC) emissions can be influenced by ambient temperature. Very low ambient temperatures (e.g., below $20{ }^{\mathrm{O}} \mathrm{F}$ ) can influence emissions at ignition and cause the catalytic converters, in vehicles that have it, to cool during short stops.

Very high ambient temperatures can also have a secondary influence on exhaust emissions because engine load is increased by air conditioner use. Effects can include higher Nitrogen oxides. The amount of water vapour in the air can affect nitrogen oxide gaseous emissions in older and malfunctioning vehicles. Concentrations of all pollutants are lower at higher wind speeds (Levy, 2003). Although CO air concentrations are generally high in areas with heavy traffic congestion, the emissions are substantially greater in cold weather because cars need more fuel to start at cold temperatures and some emission control devices such as oxygen sensors and catalytic converters operate less efficiently when they are cold (Tubal et al, 2002)

Operating characteristics involves the consideration of the, temperature, humidity, wind speed, and the degree of traffic congestion. Ambient temperature has a large direct effect on evaporative hydrocarbon emissions.
The high hydrocarbon concentration during peak periods in the four locations could be attributed to the constantly high temperature

One of the hypotheses is that concentration at peak periods is significantly influenced by weather conditions. The test results as shown in table 2 and equations 1-3 indicate a corroborated this hypothesis particularly as the parameters, are significantly correlated and influenced by temperature and relative humidity, except for Hydrocarbon.

Of the weather elements temperature does not have significant influence on all the pollutants as in equations 1 and 2 hydrocarbon concentration was not correlated with temperature and relative humidity.

$$
\begin{aligned}
& \mathrm{CO}=-33.59-0.193 \mathrm{X}_{1}+0.514 \mathrm{X}_{2}-0.342 \mathrm{X}_{3} \\
& \text { (1) } \\
& t=-0.484 \quad-0.405 \quad 1.147 \quad-0.771 \\
& \text { Sig t (0.654) (0.706) (0.315) (0.484) } \\
& \mathrm{NOx}=-0.934 \mathrm{X}+0.098 \mathrm{X}_{1}+0.446 \mathrm{X}_{2}-0.810 \mathrm{X}_{3} \\
& \text { (2) } \\
& \begin{array}{lllll}
\mathrm{t} & -0.404 & 0.305 & 1.528 & -2.798
\end{array} \\
& \text { Sig t (0.707) (0.776) (0.201) (0.049) } \\
& \mathrm{CxHy}=-1622.96-0.192 \mathrm{X}_{1}+0.452 \mathrm{X}_{2}-0.039 \mathrm{X}_{3} \\
& \text { (3) } \\
& \begin{array}{lllll}
\mathrm{t} & -0.579 & -0.372 & 0.959 & -0.083
\end{array} \\
& \begin{array}{lllll}
\text { Sig t } & (0.593) & (0.729) & (0.392) & (0.938)
\end{array}
\end{aligned}
$$

Where $X_{1}=$ air temperature; $X_{2}=$ Relative humidity; $\mathrm{X}_{3}=$ wind speed

Utang and Ogba (2009) have already reported that the synoptic wind system in Port Harcourt is characteristically calm to very gentle during most time of year as to have little influence on pollutant dispersion. This confirms the insignificant relationship and influence of wind speed as indicated in the results obtained from this study.

Another null hypothesis (Ho) states that the concentration of each pollutant during the days of air quality inventory is significantly the same between the locations and peaks periods. 
The results as presented in table $3 \mathrm{a}$ and $\mathrm{b}$ shows that the test statistics for carbon monoxide was $F$ value of 58.10 and 24.24 respectively, while critical or table values were 8.74 . Based on the statistical decision rule, we rejected the Ho, implying a significant difference in concentration of $\mathrm{CO}$ between the four locations over the days.

For Nitrogen Oxides, the test statistics gives a value of 1.08 and 2.87 while critical value is 8.74 . The null hypothesis was not hence the concentration of in NOx between the four locations in the five days of inventory was significantly the same.
Result of the test statistics for hydrocarbon follows the pattern of carbon monoxide.

\section{Temporal Variation in Air Quality in the Four Locations}

The results as shown in table 4 indicate that the mean hourly concentration for $\mathrm{CO}$ and NOx did not vary much from the mean daily in all the periods. Hydrocarbon concentration however highly deviated from the mean daily, mostly during the evening peaks and off peak.

On the null hypothesis that air quality is the same in the four days and at morning and evening peak periods, the test results are presented in table 5 .

Table 2: Correlation coefficients for relationship between air quality parameters and weather variables

\begin{tabular}{|l|l|l|l|}
\hline \multirow{2}{*}{ Coefficients } & \multicolumn{3}{|c|}{ Parameters } \\
\cline { 2 - 4 } & CO & NOx & CxHy \\
\hline $\mathrm{R}$ & 0.613 & 0.857 & 0.556 \\
\hline $\mathrm{R}^{2}(\%)$ & 37.6 & 73.4 & 31.0 \\
\hline $\mathrm{F}$ & 0.803 & 3.683 & 0.598 \\
\hline Sig F & 0.554 & 0.120 & 0.649 \\
\hline
\end{tabular}

Source: Analysis of fieldwork data, 2010 
Table 3: ANOVA Table of variation in air quality between location and peak traffic

a. Peak morning

\begin{tabular}{|c|c|c|c|c|c|}
\hline \multicolumn{6}{|c|}{ Comparison of Carbon monoxide values } \\
\hline Source of variations & $\begin{array}{l}\text { Sum } \\
\text { squares }\end{array}$ & $\begin{array}{l}\text { Degree of } \\
\text { freedom }\end{array}$ & $\begin{array}{l}\text { Mean sum of } \\
\text { squares }\end{array}$ & F Cal & Critical F \\
\hline \multirow{6}{*}{$\begin{array}{l}\text { Between Sum of Squares } \\
\text { Within Sum of Squares } \\
\text { Total Sum of Squares }\end{array}$} & 111.56 & 3 & 37.19 & \multirow[t]{3}{*}{58.10} & \multirow[t]{11}{*}{8.74} \\
\hline & 7.66 & 12 & 0.64 & & \\
\hline & 119.22 & 15 & 7.95 & & \\
\hline & \multicolumn{4}{|c|}{ Comparison of Nitrogen Oxides } & \\
\hline & 0.1925 & 3 & 0.064 & \multirow[t]{3}{*}{1.08} & \\
\hline & 0.03 & 12 & 0.069 & & \\
\hline & 1.02 & 15 & 0.068 & & \\
\hline \multicolumn{5}{|c|}{ Comparison of hydrocarbon } & \\
\hline & 186727.97 & 3 & 62242.66 & \multirow[t]{3}{*}{562.42} & \\
\hline & 1328.03 & 12 & 110.67 & & \\
\hline & 1880556 & 15 & 12537.07 & & \\
\hline
\end{tabular}

Source: Analysis result, 2010 
b. Evening Peak

\begin{tabular}{|c|c|c|c|c|c|}
\hline \multicolumn{6}{|c|}{ Comparison of Carbon monoxide values } \\
\hline Source of variations & $\begin{array}{l}\text { Sum } \\
\text { squares }\end{array}$ & $\begin{array}{l}\text { Degree of } \\
\text { freedom }\end{array}$ & $\begin{array}{l}\text { Mean sum of } \\
\text { squares }\end{array}$ & F Cal & Critical F \\
\hline \multirow{6}{*}{$\begin{array}{l}\text { Between Sum of Squares } \\
\text { Within Sum of Squares } \\
\text { Total Sum of Squares }\end{array}$} & 534.38 & 3 & 178.13 & \multirow[t]{3}{*}{24.235} & \multirow[t]{11}{*}{8.74} \\
\hline & 88.21 & 12 & 7.35 & & \\
\hline & 622.28 & 15 & 41.49 & & \\
\hline & \multicolumn{4}{|c|}{ Comparison of Nitrogen Oxides } & \\
\hline & 0.94 & 3 & 0.31 & \multirow[t]{3}{*}{2.87} & \\
\hline & 10.74 & 12 & 0.89 & & \\
\hline & 11.65 & 15 & 0.78 & & \\
\hline \multicolumn{5}{|c|}{ Comparison of hydrocarbon } & \\
\hline & 1497099.18 & 3 & 499033.06 & \multirow[t]{3}{*}{309.23} & \\
\hline & 19365.19 & 12 & 1613.77 & & \\
\hline & 1516464.37 & 15 & 101097.62 & & \\
\hline
\end{tabular}

Source: Analysis result, 2010 
Table 4: Daily average emission (for the four locations at peak and off peaks)

\begin{tabular}{|c|c|c|c|c|}
\hline \multirow[t]{3}{*}{ DAY } & \multicolumn{4}{|c|}{ PARAMETERS } \\
\hline & \multicolumn{4}{|c|}{ Morning Peak } \\
\hline & SOx (ppm) & $\mathrm{CO}(\mathrm{ppm})$ & NOx (ppm) & CxHy (5) \\
\hline 1 & 0.0003 & 5.23 & 0.38 & 83.5 \\
\hline 2 & 0.0004 & 5.9 & 0.35 & 82.8 \\
\hline 3 & 0.0004 & 5.53 & 0.48 & 74.7 \\
\hline 4 & 0.0003 & 5.35 & 0.48 & 81 \\
\hline Mean & & 5.50 & 0.42 & 80.5 \\
\hline Std dev & & 0.29 & 0.07 & 4.00 \\
\hline \multicolumn{5}{|c|}{ Evening Peak } \\
\hline 1 & 0.0002 & 15.9 & 1.03 & 210.7 \\
\hline 2 & 0.0007 & 16.2 & 1.03 & 174.6 \\
\hline 3 & 0.0006 & 16.8 & 1.01 & 207.7 \\
\hline 4 & 0.0007 & 15.5 & 0.87 & 219.9 \\
\hline Mean & & 16.1 & 0.99 & 203.2 \\
\hline Std Dev & & 0.55 & 0.077 & 19.78 \\
\hline \multicolumn{5}{|c|}{ Off Peak } \\
\hline 1 & 0 & 5.6 & 0.05 & 0 \\
\hline 2 & 0.0002 & 4.0 & 0.03 & 6.3 \\
\hline 3 & 0.00005 & 4.4 & 0.05 & 26.9 \\
\hline 4 & 0.00003 & 4.7 & 0.06 & 10.98 \\
\hline Mean & & 4.7 & 0.05 & 11.05 \\
\hline Std Dev & & 0.68 & 0.01 & 11.49 \\
\hline Grand Mean & & & & 98.26 \\
\hline Std Dev & & & & 83.7 \\
\hline
\end{tabular}

Source; Analysis result, 2010 
Table 5: ANOVA Table of variation in air quality between days and peak traffic

\begin{tabular}{|c|c|c|c|c|c|}
\hline \multicolumn{6}{|c|}{ Comparison of Carbon monoxide values } \\
\hline Source of variations & Sum of squares & $\begin{array}{l}\text { Degree of } \\
\text { freedom }\end{array}$ & $\begin{array}{l}\text { Mean sum of } \\
\text { squares }\end{array}$ & F Cal & Critical F \\
\hline \multirow{6}{*}{$\begin{array}{l}\text { Between Sum of Squares } \\
\text { Within Sum of Squares } \\
\text { Total Sum of Squares }\end{array}$} & 360.19 & 2 & 180.10 & \multirow[t]{3}{*}{47.9} & \multirow[t]{11}{*}{19.4} \\
\hline & 33.84 & 9 & 3.37 & & \\
\hline & 394.03 & 11 & 35.8 & & \\
\hline & \multicolumn{4}{|c|}{ Comparison of Nitrogen Oxides } & \\
\hline & 1.78 & 2 & 0.89 & \multirow[t]{3}{*}{296.6} & \\
\hline & 0.03 & 9 & 0.003 & & \\
\hline & 1.89 & 11 & 0.17 & & \\
\hline \multicolumn{5}{|c|}{ Comparison of hydrocarbon } & \\
\hline & 75758.69 & 2 & 57879.05 & \multirow[t]{3}{*}{174.4} & \\
\hline & 1952.39 & 9 & 216.93 & & \\
\hline & 77710.49 & 11 & 7064.6 & & \\
\hline
\end{tabular}

Source; Analysis result, 2010 
Table 6: Space-time comparison of inventory data with standards

\begin{tabular}{|c|c|c|c|c|c|c|}
\hline \multirow[t]{3}{*}{ Pollutants } & \multicolumn{4}{|c|}{ LOCATION } & \multicolumn{2}{|c|}{ STANDARDS } \\
\hline & \multicolumn{4}{|c|}{ Morning Peak } & \multirow[b]{2}{*}{ LOCAL } & \multirow[b]{2}{*}{ INTL } \\
\hline & $\mathrm{A}$ & $\mathrm{B}$ & $\mathrm{C}$ & $\mathrm{D}$ & & \\
\hline $\mathrm{CO}(\mathrm{ppm})$ & 6.8 & 7.2 & 0.95 & 7.0 & $10-20$ & 35 \\
\hline NOx(ppm) & 0.3 & 0.5 & 0.6 & 0.3 & $0.04-0.06$ & 0.053 \\
\hline SOx(ppm) & 0 & 0 & 0.0006 & 0.0004 & 0.01 & 0.03 \\
\hline СxHy(\%) & 280.3 & 3.7 & 3.4 & 50.3 & N/A & N/A \\
\hline \multicolumn{7}{|c|}{ Evening Peak } \\
\hline $\mathrm{CO}(\mathrm{ppm})$ & 25 & 14.7 & 16.2 & 8.9 & $10-20$ & 35 \\
\hline NOx(ppm) & 0.6 & 2.3 & 1.1 & 0.9 & $0.04-0.06$ & 0.053 \\
\hline SOx(ppm) & 0 & 0 & 0 & 0.0006 & 0.01 & 0.03 \\
\hline СхНу(\%) & 10.8 & 786.7 & 0.5 & 70.7 & N/A & N/A \\
\hline
\end{tabular}

Source; Analysis result, 2010

The result indicates that for all the parameters, a significant variation existed in their concentration during the days of emission inventory. The reasons for the variations could be attributed to variation in operation modes, local meteorology (atmospheric boundary layer conditions), traffic count and variations in vehicle characteristics.

\section{Comparing the levels of concentration of air quality parameters with international and National/Local standards}

From table 6, the $\mathrm{CO}$ concentration in all the locations during the morning peak periods were within both local and international standards. The value of NOx at $0.2 \mathrm{ppm}$ at location 3 is above both local and international standards while the value of SOx is within the local and international standards.From table 6 , the value of CO $25 \mathrm{ppm}$ in location $\mathrm{A}$ is above local standards but within international standards at all locations. NOx is generally above the local and international standards in all the locations while the value of SOx is within local and international standards.

The health challenges associated with high concentration of these pollutants are enormous. For example $\mathrm{NO}_{2}$ is responsible for immune system impairment, exacerbation of asthma and chronic respiratory diseases: reduced lung function and cardiovascular disease (Schwela, 2000). 
The implication of the inventory data is that if this is the usual scenario, then most hawkers, road side itinerant and semi permanent business operators are at risk of the health challenges associated with these vehicular traffic based pollution. A prevalence of chronic bronchitis and asthma in street cleaners exposed to vehicle pollutants in concentrations higher than WHO recommended guidelines, thus leading to significant increase in respiratory problems (Rachou, 1995).

\section{Recommendations}

In light of the above research project, the following recommendations have been made:

- Improvement in the condition of inner roads to reduce the number of vehicles at major intersections will help reduce the concentration of pollutants if there is no serious traffic situation in a particular area at every point in time.

- Technology changes and development in the transport sector should be carried out by the Government. The actualization of the implementation of the Monorail System proposed by the Rivers State government is a case to be reckoned with. Monorail transportation technology is unique and faster in getting the people to their destinations This will help reduce the use of private cars plying the roads, since the advancement in. The reduction in the number of vehicles plying the roads will drastically reduce traffic jam, hence vehicular emission.

- Vehicle Emission Control Technologies have been useful in reducing emission of pollutants. The city government could encourage this. There are several types of emission control technologies in use now. In developing countries especially, only catalytic converters and fuel injection systems are common.

- The construction of modern roundabouts and overhead bridges can be valuable. These improve traffic flow as well as cut down vehicular emissions and fuel consumption by reducing the vehicle idle time at intersections and thereby creating a positive impact on the environment.

\section{Conclusion}

That pollution at traffic intersection is usually high, particularly during traffic peaks and that motor vehicle remains the dominant source of urban air pollution has been confirmed. Addressing this situation requires an understanding of causal factors related to emissions. This study created the awareness that vehicular traffic at peak periods has the potential to cause pollution especially depending on the operation characteristics, meteorology, age of the vehicle and the type of fuel used in the vehicle. This research, although confined to nodal traffic points suggest that Port Harcourt is not safe from traffic related air pollution threats. Thus there is need for concerted efforts at reducing the threat in order to stem possible air pollution episodes at road intersections. This can achieved through legislative, economic and civil engineering measures.

\section{References}

Abhishek, T. and Colls, J. (2010), Air pollution Measurement, modeling and mitigation, London, Routledge

Akpan, U.G., Ndoke, P. N. (1999), Contribution of vehicular traffic emission to $\mathrm{CO}_{2}$ emission in Kaduna and Abuja. Federal University of Technology Minna Nigeria.

CEC, (1992), The state of the environment in the European Community. Overview, Vol. 3.Commission of the Communities, Brussels and Belgium.

Colls, J. (2002), Air pollution; London, Spon Press

Koku, C.A., Osuntogun, B.A. (2007), Environmental-Impacts of Road Transportation in Southwestern States of Nigeria. Journal of Applied Sciences, 7(16), 2536-2360.

Levy, J. I., Bennett, D. H., Melly, S. J. and Spengler, J. D. (2003), Influence of traffic patterns on particulate matter and polycyclic aromatic hydrocarbon concentrations in Roxbury, Massachusetts; Journal of Exposure Analysis and Environmental Epidemiology, 13, 364-371. doi:10.1038/sj.jea.7500289 
Odhiambo, G.O. Kinyua,, A.M. Gatebe, C.K.and Awange, J. (2010), Motor Vehicles Air Pollution in Nairobi, Kenya. Research Journal of Environmental and Earth Sciences, 2(4), 178-187.

Rouphail, N, M., Frey, H. C., Colyar, J. D. and Unal, A. (2001), Vehcle emissions and traffic measures: Exploratory analysis of field observations at signalized arterials. Paper presented at the $80^{\text {th }}$ Annual Meeting of the Transportation Research Board.

Saville, S. B. (1993), Automotive options and quality Management in developing Countries. Industrial Environment, 16(1-2), 20-32.

Schwela, D. (2000), Air pollution and health in urban areas. Reviews on Environmental Health, 15(12), 1324.
Tubal, G., Estoque, M. Holdsworth, J. and Villarin, J.S.J. (2002), Effect of the Diurnal of the Convective Boundary Layer Height over Metro Manila on Pollutant Science Diliman, Vol 14, No 1

USEPA. (1994), Guide to Environmental Issues, Doc. No 520/B-94-01. United States Environmental Protection Agency, Washington, DC, USA.

Utang, P. B. and Ogba, C. O. (2009), Climatological imperatives for air quality management within the coastal milieu of the Niger Delta, Nigeria; Journal of the Nigerian Environmental Society (JNES), 5(2), 1-14. 